\title{
MAKNA BONUS BAGI PENGEMUDI TRANSPORTASI ONLINE
}

\author{
Darti Djuharni1) , Wilujheng Dwi Pangesti2)
}

Sekolah Tinggi Ilmu Ekonomi (STIE) Malangkuçeçwara

Jalan Terusan Kalasan - Malang - Jawa Timur - 65142

E-Mail:dartidjuharni@yahoo.com

Akuntansi Bisnis dan Manajemen (ABM), Vol. 27

No. 1,

Halaman 66-76

Bulan April, Tahun 2020

ISSN 0854-4190

E-ISSN 2685-3965
Informasi Artikel

Tanggal Masuk:

5 April 2020

Tanggal Revisi:

20 April 2020

Tanggal Diterima:

28 April 2020

\section{Abstract}

The interpretive paradigm used in this study is intended to uncover the meaning of bonuses for online transportation drivers. The existence of benefits felt by the community towards the existence of online transportation, encourages researchers to study it further. Nine online transportation drivers in Malang were used as informants in this study. Interviews were conducted based on the willingness of the drivers and conducted while the person was waiting for the order. Based on the results of the analysis that has been done, the meaning of bonuses revealed in this study are: Fulfillment of Basic Needs, Performance Enhancement, Fulfillment of Safety and Comfort, and Existence of Achievement Assessment.

Keywords: The meaning of bonuses; online transportation; interpretive paradigms

\begin{abstract}
Abstrak
Paradigma interpretif yang digunakan dalam penelitian ini ditujukan untuk mengungkap makna bonus bagi pengemudi transportasi online. Adanya manfaat yang dirasakan masyarakat terhadap keberdaaan transportasi online, mendorong peneliti untuk mengkajinya lebih jauh. Sembilan orang pengemudi transportasi online yang ada di kota Malang dijadikan sebagai informan dalam penelitian ini. Wawancara dilakukan berdasarkan kesediaan para pengemudi tersebut dan dilakukan saat yang bersangkutan sedang menunggu orderan. Berdasarkan hasil analisis yang telah dilakukan, makna bonus yang terungkap dalam penelitian ini yaitu: Pemenuhan Kebutuhan Dasar, Peningkatan Kinerja, Pemenuhan Rasa Aman dan Nyaman, serta Adanya Penilaian Prestasi.
\end{abstract}

Kata Kunci: Makna Bonus; transportasi online; paradigma interpretif 


\section{PENDAHULUAN}

Transportasi online saat ini sedang menjadi trend di masyarakat karena kemudahan serta kepraktisannya dalam melayani penumpang dibandingkan dengan transportasi umum yang konvensional. Hal ini sebagaimana disampaikan oleh Rusy and Fathy (2018) bahwa transportasi online memenuhi tiga kriteria utama yang dibutuhkan oleh penumpang, yaitu keamanan, kepastian, dan kecepatan. Kondisi ini tidak lepas dari adanya kemajuan teknologi dan komunikasi. Dunia teknologi dan komunikasi mengalami perkembangan yang sangat pesat. Berbagai inovasi terus bermunculan dalam kehidupan masyarakat. Salah satu diantaranya adalah penggunaan smartphone yang memiliki kemampuan tinggi dengan fungsi yang menyerupai komputer. Maraknya pengguna smartphone menjadikan masyarakat sangat bergantung pada teknologi ini, tidak terkecuali ketergantungan terhadap transportasi online.

Kehadiran transportasi online saat ini menjadi idola bagi konsumen, khususnya yang tidak memiliki kendaraan pribadi atau tidak dapat mengendarai sendiri (Agustin, 2017). Sebelum adanya transportasi online apabila kita memerlukan layanan transportasi, seperti taksi misalnya, maka kita harus menelepon terlebih dahulu atau harus berjalan menuju pangkalan. Berbeda kondisi ini dengan adanya transportasi online. Saat ini, jika kita membutuhkan transportasi, cukup menekan tombol pada layar smartphone, maka transportasi yang diinginkan langsung datang menemui kita dan siap mengantarkan sampai tujuan (Mahargiono \& Cahyono, 2017). Layanan yang disediakan oleh transportasi ini tidak terbatas hanya pada pengantaran penumpang saja, melainkan sudah mengarah ke berbagai layanan lain, seperti jasa pembelian makanan, pengiriman barang, pembelian tiket nonton bioskop, layanan pijat, home care, pemesanan hotel, dan layanan pembayaran tagihan. Kehadiran transportasi online ini sudah menjadi penyangga bagi fasilitas publik di Indonesia, meskipun pemerintah belum menentapkannya sebagai transportasi umum (Lingga, 2019).

Kehadiran transportasi online juga dapat membantu menyejahterakan perekonomian masyarakat, terutama bagi mereka yang ingin mencari penghasilan dengan waktu yang lebih fleksibel salah satu caranya adalah menjadi sopir pada transportasi jenis ini. Pekerjaan sebagai sopir transportasi online bagi sebagian orang dilakukan untuk mengisi waktu luang atau mendapatkan penghasilan tambahan, sedangkan sebagian yang lainnya dijadikan sebagai pekerjaan tetap (Subagyo, Muchsini, \& Abidin, 2019). Pilihan sebagai pengemudi transportasi online dilakukan dengan berbagai alasan antara lain, lebih praktis (Mahargiono \& Cahyono, 2017) fleksibel, standar penghasilan yang cukup tinggi, dan adanya bonus (Nurhidayah, 2018) sebagai tambahan penghasilan tetap mereka.

Penghasilan yang diperoleh pengemudi dianggap sudah cukup untuk memenuhi kebutuhan sehari-hari mereka, namun bagi seorang pekerja/pengemudi mereka menginginkan lebih untuk mendapatkan tambahan pendapatan mereka, salah satu caranya dengan mendapatkan bonus. Bonus merupakan segala sesuatu yang diterima para karyawan sebagai balas jasa untuk kerja mereka (Handoko, 2014, p. 155). Untuk memperoleh bonus pada transportasi online ada syarat yang harus dipenuhi oleh seorang pengemudi. Persyaratan yang ditentukan oleh perusahaan adalah dengan menjaga rating atau performa mereka. Rating atau performa ini merupakan penilaian dari 
konsumen terhadap kinerja pengemudi transportasi online. Penilaian ini antara lain tidak adanya pembatalan (cancellation) dari pihak pengemudi, tidak menolak pemesanan (order), dan selalu merespon pemesanan (Pramono, 2016). Semua persyaratan yang ditentukan untuk mendapatkan bonus harus terpenuhi, jika tidak, maka mereka terancam tidak akan mendapatkan bonus, padahal bonus tersebut menjadi tulang punggung untuk mendongkrak pendapatan (Nurhidayah, 2018). Selain itu perhitungan bonus didasarkan pada poin yang diperoleh pengemudi sesuai ketetapan yang berlaku. Besarnya poin dan wilayah kerja pengemudi akan berbeda antara satu dengan lainnya (Gojek, 2019; Ikhsanti, 2019).

Beberapa peneliti terdahulu yang mengkaji bonus untuk pengemudi transportasi online, antara lain Nurhidayah (2018). Dalam penelitiannya, ia mengungkapkan bahwa bonus berpengaruh secara signifikan terhadap kinerja pengemudi. Penelitiannya dilakukan di daerah Tangerang Selatan terhadap 62 orang pengemudi transportasi online yang tingkat pendidikannya bermacam-macam mulai SD sampai dengan Sarjana dan telah berpengalaman dalam menjalankan transportasi online. Penelitian lain dilakukan oleh Abdussamad (2014) menyimpulkan bahwa kompensasi menunjukkan pengaruh yang signifikan terhadap produktivitas kerja karyawan.

Penelitian terkait transportasi online yang berhasil ditemukan oleh penulis antara lain dilakukan oleh Mahargiono and Cahyono (2017), mereka mengungkapkan bahwa adanya kontroversi antara pengemudi ojek pangkalan dan pengemudi ojek online. Hasil penelitian mereka mengungkapkan bahwa beberapa pengemudi ojek pangkalan masih tetap bertahan dengan kondisinya karena mereka memperoleh nilai-nilai moral yang tidak ditemukan pada pengemudi ojek online, di sisi lain pengemudi ojek online merasakan banyak manfaat yang diperoleh dengan pekerjaan yang dilakukannya.

Manfaat adanya transportasi online dikemukakan oleh Halim and Erlinawati (2017). Mereka menyatakan adanya ojek online memberikan perubahan sosial pada masyarakat Solo, hal ini ditunjukkan pada hasil penelitiannya bahwa dari sisi penumpang memperoleh berbagai manfaat antara lain kemudahan dalam mencari transportasi yang dibutuhkan, tidak terbatas pada jarak dan waktu, serta terjaminnya keamanan dan kenyamanan karena dilakukan secara transparan melalui aplikasi. Dari sisi pengemudi juga merasakan manfaatnya antara lain tidak perlu menunggu antrian sebagaimana yang dilakukan oleh ojek pangkalan, memberikan jaminan kesejahteraan kepada keluarganya, serta dapat membagi waktu untuk melakukan pekerjaan lainnya.

Belum banyak ditemukan penelitian yang terkait dengan bonus bagi pengemudi transportasi online mendorong penulis untuk mengkaji lebih lanjut topik ini. Merujuk pada penelitian yang dilakukan oleh Nurhidayah (2018), kajian ini dilakukan untuk mengungkap makna bonus bagi pengemudi transportasi online, dengan harapan hasil penelitian ini akan memberikan manfaat bagi berbagai pihak yang membutuhkan baik secara teoretis maupun praktis.

\section{KAJIAN PUSTAKA}

\section{Penilaian Prestasi Kerja}

Berbagai faktor dapat dilakukan perusahaan untuk meningkatkan motivasi dan prestasi kerja karyawan. Prestasi kerja yang dengan kata lain biasa disebut dengan 
kinerja merupakan salah satu penilaian terhadap keberhasilan suatu perusahaan. Saputra (2013) menyebutkan ada dua aspek dalam mengukur kinerja perusahaan yaitu aspek keuangan dan non keuangan. Aspek non keuangan dinyatakan lebih memegang peran yang lebih besar dibandingkan aspek keuangan, karena di aspek ini lebih banyak faktor yang dijadikan bahan penilaian, salah satu diantaranya adalah sumber daya manusia. Kinerja dari sumber daya manusia dapat ditingkatkan dengan berbagai cara salah satunya adalah dengan memberikan kompensasi yang layak.

Pemberian kompensasi merupakan kewajiban perusahaan yang didasarkan pada prestasi kerja, dan dilakukan secara adil, serta diberikan tepat waktu (Firmandari, 2014). Senada dengan apa yang disampaikan Firmandari sebelumnya, Murty and Hudiwinarsih (2012) menyebutkan ada dua hal yang perlu menjadi perhatian perusahaan terkait dengan kompensasi yang diberikan yaitu kompensasi harus dapat dirasakan adil oleh karyawannya, dan besarnya kompensasi mendekati apa yang diperkirakan oleh karyawan. Dengan demikian menurut mereka karyawan baru akan merasa puas, jika kedua hal ini menjadi perhatian dan dilaksanakan oleh perusahaan. Masih menurut Murty and Hudiwinarsih (2012), jenis kompensasi yang biasa diterima oleh karyawan secara teratur dengan jumlah yang tetap disebut gaji atau upah, tetapi ada juga kompensasi lain yang besarannya bervariasi tergantung pada prestasi yang dihasilkan oleh setiap karyawan. Bentuk kompensasi ini dapat berupa insentif atau bonus.

Bonus dalam kajian ini diartikan sebagai tambahan penghasilan yang akan diperoleh seseorang di samping gaji. Bonus terbukti dapat memotivasi dan meningkatkan kinerja karyawan seperti yang disampaikan oleh Nurhidayah (2018), bahwa kompensasi yang diberikan perusahaan kepada pengemudi transportasi online berpengaruh secara signifikan terhadap kinerja. Hal ini sesuai dengan kriteria bonus yang diberikan kepada pengemudi oleh perusahaan transportasi online (Gojek, 2019)

\section{Pemanfaatan Transportasi Online}

Berbagai transportasi umum yang biasa digunakan masyarakat untuk membantu mencapai tujuan tertentu, secara konvensional dilakukan dengan cara mendatangi tempat mangkalnya kendaraan tersebut atau menunggu di pinggir jalan. Masyarakat yang ingin menuju suatu tempat tertentu tanpa harus berbagi dengan orang lain biasanya menggunakan taksi, ojek, atau bajay. Cara yang digunakan agar bisa memperoleh kendaraan yang diinginkannya itu dilakukan dengan cara menelpon atau menunggu di pinggir jalan menanti kendaraan yang lewat.

Di era sekarang ini, kebutuhan dan keinginan masyarakat menuntut sesuatu yang lebih praktis dan efisien. Adanya transportasi online yang marak saat ini sangat membantu masyarakat, karena untuk menuju ke suatu tempat cukup dengan menggunakan aplikasi melalui smartphone, maka kendaraan yang diinginkan akan datang menjemput kita di tempat yang telah ditentukan. Perbedaan cara dan sikap masyarakat dengan masuknya transportasi online ini dirangkum oleh Halim and Erlinawati (2017) sebagaimana tabel 1 berikut ini. 
Tabel 1 Perbedaan Manfaat antara transportasi konvensional dan online

\section{Transportasi Konvensional}

Pemesanan dilakukan dengan cara mendatangi tempat "mangkal" transportasi yang diinginkan

Adanya keterbatasan waktu dan jarak yang Keamanan dan kenyamanan kurang terjamin

Belum ada kolaborasi antara perusahaan transportasi dengan penggunaan teknologi informasi

Standar operasional masih kurang dalam pelaksanaan transportasi

\section{Transportasi Online}

Cukup melakukan pemesanan melalui smartphone

Tidak ada batasan waktu dan jarak

Terjaminnya keamanan dan

kenyamanan karena identitas sopir dan kendaraan terekam lewat aplikasi.

Ada kolaborasi yang jitu antara perusahaan transporasi dengan penggunaan teknologi informasi Ada standar operasional yang baku dan tersistem dengan baik disamping, serta system yang transparan

Hadirnya transportasi online di tengah masyarakat tentu saja menjadi ancaman bagi transportasi konvensional, sehingga di awal masuknya transportasi ini banyak penolakan yang dilakukan oleh para pengemudi transportasi konvensional dengan cara melakukan demonstrasi untuk menolak masuknya transportasi ini kepada pemerintah. Selain itu ada juga yang melakukan tindakan anarkis dengan menganiaya pengemudi transportasi online yang memasuki daerah "kekuasaan" transportasi konvensional.

Kondisi ini mendorong Prabawati and Harsono (2017) untuk meneliti tentang strategi pemasaran yang dilakukan taksi Bluebird. Dari hasil penelitian mereka menyebutkan bahwa perusahaan taksi Bluebird memiliki beberapa keunggulan dan kekurangan dibandingkan dengan transportasi online, sehingga disarankan untuk melakukan penyempurnaan strategi agar perusahaan tetap eksis dan dapat bersaing dengan perusahaan transportasi online.

\section{METODE PENELITIAN}

Jenis penelitian kualitatif yang digunakan di sini menggunakan paradigma interpretif dengan alasan sebagaimana disampaikan Creswell (2013, p. 44). Ia menyatakan bahwa peneliti kualitatif adalah peneliti interpretif, sehingga penggunaan paradigma interpretif ditujukan pada saat seorang peneliti ingin mengungkap hal-hal yang sangat ingin diketahuinya dan tidak akan diperoleh jawaban jika menggunakan paradigma lain. Penelitian dengan pendekatan interpretif dapat memunculkan hal-hal yang tidak diketahui oleh orang lain, karena penelitian ini dilakukan sendiri oleh peneliti, diamati secara langsung, dan direduksi serta dianalisis sendiri. Dari kegiatan ini diharapkan data yang terkumpul akan sesuai dengan apa yang diharapkan. Djamhuri (2012) menyatakan bahwa paradigma interpretif lebih menekankan pada keunikan dan kesubyektifitasan, karena cenderung lebih menekankan pada temuan yang sifatnya lokalitas. Oleh karena itu, hasil penelitian ini tidak dapat digeneralisir di semua keadaan dan di segala tempat.

Penelitian ini dilakukan di daerah Malang raya terhadap sembilan orang pengemudi transportasi online yaitu yang bergabung pada perusahaan Gojek dan Grab. 
Pemilihan informan dilakukan secara acak terhadap para pengemudi gojek dan grab yang sedang menunggu orderan dan bersedia meluangkan waktunya untuk bercerita dan memberikan informasi terkait pekerjaan yang dilakukannya. Selain itu informan yang dipilih juga merupakan pengemudi saat peneliti menjadi penumpangnya.

Pengumpulan data dilakukan melalui wawancara mendalam dengan para pengemudi transportasi tersebut. Sembilan informan yang berhasil diwawancarai ditunjukkan pada tabel 2 berikut ini.

Tabel 2 Informan Penelitian

\begin{tabular}{|c|c|c|c|c|c|}
\hline & Nama Informan & Umur & Status & $\begin{array}{c}\text { Lama } \\
\text { bekerja }\end{array}$ & Jenis T. $\mathrm{O}^{*}$ ) \\
\hline 1. & Andra & 22 tahun & Mahasiswa & 1 tahun & Grab \\
\hline 2. & Hilmi & 21 tahun & Mahasiswa & 3 bulan & Grab \\
\hline 3. & Adit & 30 tahun & Lulusan D3 & 2 tahun & Grab \\
\hline 4. & Anto & 32 tahun & SMK & 1 tahun & Gojek \\
\hline 5. & Yanes Widianto & 40 tahun & SMK & 3 tahun & Grab \\
\hline 6. & Wahyudi Kusuma & 43 tahun & Sarjana & 2 tahun & Grab \\
\hline 7. & Heri Permadi & 35 tahun & SMK & 3 tahun & Gojek / grab \\
\hline 8. & Supriadi & 67 tahun & Purnawirawan & 2 tahun & Grab \\
\hline 9. & Warsito & 60 tahun & Pensiunan Swasta & 3 tahun & Gojek \\
\hline
\end{tabular}

*) transportasi online

Topik wawancara diawali dengan tanya jawab secara umum untuk menjalin keakraban dengan informan, kemudian dilanjutkan ke topik-topik seputaran pekerjaan informan dan mengerucut ke pertanyaan yang terkait dengan bonus. Berdasarkan pengamatan dan hasil wawancara tersebut selanjutnya peneliti menganalisis data dengan cara mengklasifikasikan data berdasarkan tema/topik tertentu, kemudian mereduksi data yang tidak relevan, dan menentukan tema berdasarkan makna yang terungkap dari masing-masing informan.

\section{HASIL DAN PEMBAHASAN}

Kehadiran transportasi online sangat membantu masyarakat khususnya yang tidak memiliki kendaraan pribadi atau yang tidak bisa mengemudikan kendaraan untuk menuju lokasi tertentu tanpa dibatasi oleh waktu dan jarak. Hal ini dikarenakan lebih praktis, efektif, dan efisien dilihat dari sudut pandang penumpang, sedangkan dari sisi pengemudi pekerjaan ini merupakan peluang untuk meningkatkan kesejahteraannya di bidang ekonomi karena dapat dilakukan secara fleksibel, baik bagi pengemudi paruh waktu maupun yang menjadikannya sebagai pekerjaan utama. Berbagai upaya telah dilakukan perusahaan transportasi online untuk memberikan kenyamanan tidak saja kepada penumpang dengan berbagai promo yang ditawarkan, terlebih lagi kepada pengemudi.

Adanya transportasi online mengubah sudut pandang masyarakat terhadap pengemudinya. Profesi sebagai pengemudi transportasi online tidak lagi dipandang sebelah mata atau sebagai profesi rendahan karena berbagai kalangan banyak yang melakukan pekerjaan ini, sehingga citranya di masyarakat menjadi lebih baik (Halim \& 
Erlinawati, 2017). Berbagai alasan dilakukan seseorang untuk menjadi pengemudi transportasi online, salah satu di antaranya adalah karena adanya bonus yang diberikan oleh perusahaan. Besarnya bonus tergantung pada wilayah tertentu dan performa pengemudinya (Gojek, 2019), namun meskipun bonus berbentuk materi yang diterima oleh pengemudi, tetapi makna bonus bagi setiap informan bermacam-macam. Berdasarkan hasil wawancara dan analisis yang dilakukan, peneliti menemukan berbagai macam makna bonus yang tidak hanya sekedar materi saja, tetapi ada hal lain yang dimaknai oleh para informan. Berikut ini diuraikan berbagai makna bonus yang ditemukan:

\section{Pemenuhan Kebutuhan Dasar}

Bonus yang diterima oleh setiap informan digunakan untuk berbagai macam kebutuhan, karena setiap orang mempunyai kebutuhan yang berbeda. Perbedaan kebutuhan ini dapat hasil wawancara ke beberapa informan, seperti yang dikatakan Andra sebagai seorang mahasiswa.

...kebetulan ini pekerjaan sampingan mbak soalnya saya juga sambil kuliah jadi ini buat nambah-nambah uang jajan sih mbak sama uang kuliah saya juga". Sebagai mahasiswa ia masih mengandalkan kiriman dari orang tuanya, sehingga penghasilannya sebagai pengemudi transportasi online dimanfaatkan untuk menambah kebutuhannya sebagai mahasiswa.

Lain halnya dengan Heri yang yang menjadi pengemudi di dua perusahaan transportasi sekaligus. Ia menjadikan pekerjaannya sebagai profesi utama, sehingga bonus yang diperoleh dimanfaatkan untuk membiayai kebutuhan sehari-hari sebagaimana hasil wawancara yang dikutip sebagai berikut. ...kalau bagi saya bonus itu tambahan buat memenuhi kebutuhan saya sehari-hari berupa uang, buat makan, bayar cicilan mobil, perawatan mobil, buat anak dan istri juga makanya saya jalan 2 aplikasi.

Informan Supriadi memanfaatkan bonus yang diperoleh untuk berjaga-jaga jika ada kondisi darurat, seperti yang dikatakannya : ..." biasanya saya kumpulin buat beli ban, ganti oli, tapi kalau kepepet bisa buat beli obat".

Berdasarkan hasil wawancara yang diungkapkan sebelumnya, tampak bahwa setiap pengemudi memiliki kebutuhan yang berbeda-beda dan bonus yang diperoleh dimanfaatkan untuk berbagai kebutuhan mereka.

\section{Peningkatan Kinerja}

Selain untuk memenuhi kebutuhan dasar, bonus yang diperoleh menurut para informan dapat memotivasi diri untuk meningkatkan kinerja. Besarnya bonus yang diperoleh masing-masing pengemudi dihitung berdasarkan jumlah poin yang dikumpulkan dalam satu hari, sehingga penerimaan bonus akan berbeda antara pengemudi yang satu dengan yang lainnya. Cara mendapatkan bonus disampaikan oleh informan Antony sebagai berikut.

...kalau dari perusahaan itu kita harus menjaga rating performa kita sehingga perusahaan pun tidak di rugi kan, cara nya supaya rating kita tetap bagus, dengan cara tidak terlalu sering cancel orderan, trus memberikan pelayanan yang terbaik ke konsumen sehingga konsumen memberikan rating yang bagus juga ke kita.

...kalau di grab kan sistemnya disebut berlian,untuk 10 berlian itu antar atau jemput konsumen, kalau makanan 15-18 berlian cuman kalau di jam-jam tertentu bisa lebih. 
Ketika ditanyakan apakah bonus bisa menjadi motivasi, dijawab dengan yakin dan lantang, ...pasti mbak soalnya itu diibaratkan penyemangat kita, bisa bantu untuk biaya-biaya lainnya

Hal senada juga disampaikan oleh Adit yang menunjukkan bagaimana ia dapat memperoleh bonus,

...jadi gini loh mbak kalau di Grab ada 5 tahap, yang pertama Rp.30.000, yang kedua Rp.75.000, yang ketiga Rp. 150.000, yang titik keempat Rp.200.000, yang kelima Rp.250.000, alasan saya ngejar target itu soalnya uang bonus buat operasional sehari-hari ya bensin, makan nah kalau saya gak ngejar saya gak akan dapat bayaran tapi enaknya di ojek online ini bisa nentuin yang mana kalau mau yang full harus nya berangkat pagi sampe malam, full ya dapat Rp. 250.000 sudah bersih mbak.

Berdasarkan hasil wawancara ini, tampak bahwa setiap pengemudi akan memperoleh bonus berdasarkan prestasi yang dicapainya, sehingga bonus dijadikan sebagai alat motivasi untuk meningkatkan kinerja.

\section{Pemenuhan Rasa Aman dan Nyaman}

Selain untuk memenuhi kebutuhan pokok dan memotivasi agar setiap individu dapat meningkatkan kinerjanya. Ternyata bonus juga dapat memberikan rasa aman dan nyaman kepada para pengemudi transportasi online, karena mereka bekerja tidak semata-mata mengejar materinya, tetapi juga memperhatikan keselamatan penumpang dan kemampuan diri. Hal ini terungkap dari hasil wawancara kepada beberapa informan berikut.

" kalau saya tidak terlalu mengejar bonus secara financial ya mbak, yang penting saya utamakan pelayanan saya ke konsumen soalnya kan ini kita jual jasa kita ya, jadi kita harus baik dan ramah ke konsumen, kalau saya nerapin senyum dan sapa ke konsumen jadi kalau konsumen kita senang, maka kita pun akan nyaman jadi ojol ini tanpa adanya tekanan "(Andra)

" bonus dan insentif itu akan mengikuti menurut saya, tujuan utama saya bukan bonus secara financial, kalo masing-masing individu di drive hanya untuk bonus dan insentif, setiap pengemudi pasti gak akan peduli satu sama lain, pengemudi tranportasi online soalnya kan saya kerja nya rajin jadi walaupun saya tidak mengejar bonus ya cukup aja"(Supriadi)

...soalnya kalau saya terlalu ngejar bonus secara materi takutnya saya malah gak nyaman sama pekerjaan saya mbak, jadi saya lebih memilih kerja dengan santai dan pasti tapi memenuhi target (Adit).

....saat ini saya tidak terlalu mengejar bonus, saya juga harus memperhatikan kondisi badan saya, yang penting saya bisa melayani konsumen dengan baik dan istirahat cukup, kalau memang rezeki saya pasti tidak akan kemana-mana (warsito). Selanjutnya dikatakannya, ...terkadang saya tidak mendapatkan bonus sama sekali dari pekerjaan saya ini, tapi saya dapat rezeki dari penumpang offline. Jadi...sama aja khan?he..he..katanya sambil tertawa.

Dari hasil wawancara dengan beberapa informan itu, tampak bahwa tidak semua pengemudi mengejar bonus secara finansial tetapi mereka juga mementingkan keamanan pihak lain dan kenyamanan diri mereka, apalah artinya menerima bonus yang besar tetapi akhirnya jatuh sakit karena kelelahan. 


\section{Penilaian Prestasi}

Bonus selain dimaknai untuk pemenuhan kebutuhan dasar, peningkatan kinerja, dan kebutuhan rasa aman dan nyaman, juga ditujukan sebagai penilaian prestasi. Tidak akan ada bonus tanpa adanya prestasi. Prestasi yang dicapai oleh seorang pengemudi dinilai dari beberapa aspek antara lain, kepuasan konsumen yang biasanya ditandai dengan pemberian bintang lima terhadap pengemudi yang telah melayani konsumennya dengan baik, tidak sering melakukan "cancel" terhadap order yang masuk, serta pencapaian target yang ditetapkan perusahaan. Hal ini sebagaimana diungkapkan Heri:

...Kita tidak bisa macam-macam disini mbak di Grab maupun Go-jek karena kalo ada konsumen yang protes, terutama dari cara pelayanan, langsung melapor ke kantor dan otomatis kantor langsung memberikan teguran berupa akun akan di-suspend dan kalau akun sudah di-suspend maka kita tidak bisa lagi terima orderan. Disuspend itu sama dibekukan akunnya, sebenarnya kita tetap masih bisa masuk lagi, tapi kalo buat akun baru atas nama orang lain, tapi kendaraan lain yang kita bawa, itu kalo kendaraan yang punya lebih dari satu karena nomor plat kendaraan yang dulu sudah terdaftar.

Hal lain disampaikan oleh Adit bahwa kalau mau kerja keras, bonus itu akan mengiringi prestasi kita,

"kalau menurut saya makna bonus itu hasil dari kerja keras kita yang kita capai atau sebuah prestasi lah mbak, soalnya kalau kita berhasil mencapai target dari perusahaan, maka itu sebuah kebanggaan tersendiri buat diri kita, jadi perusahaan diuntungkan maka kita pun diuntungkan"

Berdasarkan prestasi kerja yang ditunjukkan oleh pengemudi, perusahaan telah menetapkan besaran bonus yang ketentuannya telah disampaikan saat pengemudi bergabung di perusahaan transportasi yang dipilihnya. Dengan demikian pengemudi dapat menghitung sendiri berapa bonus yang akan diperolehnya dengan kinerja yang dilakukan, serta bagaimana cara meraih bonus tersebut tergantung strategi dan cara kerja masing-masing pengemudi.

\section{KESIMPULAN DAN SARAN}

Dari hasil penelitian yang telah diuraikan sebelumnya dapat disimpulkan bahwa bonus tidak hanya dimaknai sebagai materi belaka, melainkan banyak hal yang dapat dirasakan oleh para pengemudi transportasi online terkait dengan bonus yang diperoleh. Bonus dapat menjadi sarana pemenuhan kebutuhan dasar, bonus sebagai alat motivasi untuk meningkatkan kinerja, bonus dapat memberikan rasa aman dan nyaman, serta bonus merupakan bentuk penilaian prestasi yang diberikan perusahaan kepada para pengemudi.

Penelitian ini masih memiliki keterbatasan karena proses wawancara kadangkadang terganggu dengan kondisi sekitarnya seperti munculnya kendaraan lain dengan suaranya yang keras sehingga mengganggu jalannya wawancara. Selain itu di saat sedang wawancara ternyata informan yang bersangkutan menerima orderan, sehingga wawancara terputus. Penelitian dengan topik bonus transportasi online ini masih dapat dikaji lebih lanjut, seperti system pembayaran dan penerimaan bonus, 
atau dari sisi penumpang dapat dilihat bagaimana tingkat kepuasan konsumen terhadap layanan transportasi online.

\section{DAFTAR PUSTAKA}

Abdussamad, Zuchri. (2014). Pengaruh Kompensasi Terhadap Produktivitas Kerja Karyawanpada Pt Asuransi Jiwasraya Gorontalo. Jurnal Manajemen/Volume Volume XVIII(No. 03), 456-466.

Agustin, Anis. (2017). Persepsi Masyarakat Terhadap Penggunaan Transportasi Online (GOJEK) Di Surabaya. STIESIA SURABAYA.

Creswell, John W. (2013). Qualitative Inquiry and Research Design: Choosing Among Five Approaches (Third ed.). USA: Sage Publication, Inc.

Djamhuri, Ali. (2012). Interpretive Research in Accounting: A philosophical and methodological Exploration. Paper presented at the The Fourth UB International Consortium on Accounting, Universitas Brawijaya Malang.

Firmandari, Nuraini. (2014). Pengaruh Kompensasi Terhadap Kinerja Karyawan Dengan Motivasi Kerja Sebagai Variabel Moderasi. Jurnal Ekonomi dan Bisnis Islam, Vol. IX(No. 1), 25-34.

Gojek. (2019). Info Bonus dan Poin untuk Driver Gojek dan GoCar Retrieved 29 April, 2020, from https://driver.go-jek.com/s/article/Info-Bonus-dan-Poin-untukDriver-Gojek-dan-GoCar

Halim, Chandra, \& Erlinawati, Mira. (2017). Fenomena Ojek Online dan Dampak Sosial bagi Masyarakat Solo. Paper presented at the Seminar Nasional Teknologi Informasi dan Bisnis (SENATIB) 2017, Surakarta.

Handoko, T. (2014). Manajemen Personalia \& Sumber daya manusia (2 ed.). Yogyakarta: BPFE.

Ikhsanti, Dyah. (2019). Perbedaan Perhitungan Penghasilan Grab dan Gojek (Update 2019) Retrieved 29 April 2020, 2020, from https:// www.aturduit.com/articles/skema-honor-transportasi-online/

Lingga, Murti Ali. (2019). Ketika Ojek Online Jadi Penyokong Transportasi Publik di Tanah Air Retrieved 29 April 2020, from https:/ / ekonomi.kompas.com/read/2019/02/11/185313526/ketika-ojekonline-jadi-penyokong-transportasi-publik-di-tanah-air

Mahargiono, Pontjo Bambang, \& Cahyono, Krido Eko. (2017). Kontroversi Transportasi Online Sebagai Dasar Pembenahan Fasiltas Layanan Penumpang Bagi Pelaku Bisnis Transportasi Di Surabaya. Paper presented at the Seminar Nasional Multi Disiplin Ilmu \& Call For Papers Unisbank Ke-3 (Sendi_U 3). 
Murty, Windy Aprilia, \& Hudiwinarsih, Gunasti. (2012). Pengaruh Kompensasi, Motivasi Dan Komitmen Organisasional Terhadap Kinerja Karyawan Bagian Akuntansi (Studi Kasus Pada Perusahaan Manufaktur Di Surabaya). The Indonesian Accounting Review (TIAR), Volume 2(No. 2), 215-228.

Nurhidayah, Fitriyah. (2018). Analisis Sistem Kompensasi Terhadap Kinerja Driver Transportasi Online. Jurnal Akuntansi Maranatha, $10(2$ ), 179-186.

Prabawati, Dwi Karyayuris, \& Harsono, Soni. (2017). Strategi pemasaran jasa transportasi taksi konvensional menghadapi persaingan jasa transportasi berbasis aplikasi online di Surabaya. Journal of Business and Banking, Volume 7 (Number 1), 105-124. doi: 10.14414/jbb.v7i1.973

Pramono. (2016). Curhat Driver Gojek soal Bonus tak cair Gara-Gara Sistem Rating Retrieved 3 Oktober, 2017, from http://news.liputan6.com

Rusy, \& Fathy. (2018). Modal Sosial Ojek Pangkalan: Adaptasi Terhadap Aplikasi Online Transportasi Publik. Jurnal Masyarakat E Budaya, Volume 20( nomor 2 ), 191-210.

Saputra, Boby Wiryawan. (2013). Faktor-Faktor Yang Mempengaruhi Penilaian Kinerja. Finance \& Accounting Journal, Vol. 2(No. 2), 15-41.

Subagyo, Shangriani Yona, Muchsini, Slamet, \& Abidin, Agus Zainal. (2019). Transportasi Online dan Perubahan Sosial dan Ekonomi Masyarakat (Studi Kasus Pada Driver Transportasi Online Di Kota Malang). Jurnal Respon Publik, 13(4), 25-29. 